\section{Andrej Kutarňa}

University of South Bohemia in České Budějovice kutara00@tf.jcu.cz

ORCID: 0000-0003-3563-1139

DOI: http://dx.doi.org/10.12775/BPTh.2020.008
Biblica

et

Patristica

Thoruniensia

13 (2020) 2: 189-198

ISSN (print) 1689-5150

ISSN (online) 2450-7059

\title{
Hierarchy and Likeness - Ways to Union with God in Pseudo-Dionysius and Aquinas
}

\begin{abstract}
The influence of Pseudo-Dionysius' apophatic theology, especially of his treatise On the Divine Names, is well documented. My aim is to explore a different theme of his work, of which an echo could possibly be found in later authors including Aquinas. One of the key elements in the oeuvre of the Areopagite is his idea of relationship between the earthly and heavenly, between the celestial and ecclesial - as if one was mirroring the other.

The idea of the Image of God in Man is nothing new; the Fathers have been commenting on Gn 1:26 and developing this theme from the earliest centuries. It could be argued that the Image is not something "static" so to speak but has a dynamic aspect of procession from the original and return back to the original, of exitus and reditus. This notion of exitus and reditus is very deeply interwoven in the whole of Aquinas's Summa Theologiae and may allow one of many possible approaches to thinking about Man and his return to God.

In this paper I will try to argue that Dionysius' notion of hierarchies is very closely connected with Aquinas' use of the terms imago and similitudo and I will attempt to trace possible influences of Dionysius in this aspect of anthropology of the Angelic Doctor.
\end{abstract}

Keywords: Pseudo-Dionysius; anthropology; hierarchy; union; imago Dei.

\section{Acknowledgment}

This work was supported by the South Bohemia University grant GAJU No. $081 / 2019 / \mathrm{H}$. 


\section{Introduction}

$\mathrm{T}$ he influence of the anonymous or pseudonymous 6th century Syrian monk on future generations of theologians both in the East and the West is undisputed. For St Thomas he was one of the most often quoted patristic authors. The words "Dionysius dicit" are found over six hundred times in the Summa theologiae. ${ }^{1}$ References to Dionysius are also to be found in his other works including the biblical commentaries, where he is often quoted in order to illustrate the scriptural references. ${ }^{2}$ Of course, establishing the true connections between patristic sources can be difficult and often it is only a matter of "traces".

For Aquinas - as for many of his contemporaries - Dionysius would be the authority in the matters connected to angels and their relation to humankind. ${ }^{3}$ His influence, however, was not limited to knowledge about celestial beings. Already in the first question of the Summa theologiae we find St Thomas calling upon the authority of Dionysius in matters which could be described as "methodological" or "hermeneutical"- the use of metaphors when speaking about things divine. ${ }^{4}$

It could be argued that Dionysius himself does not employ the "classical" patristic theme of imago Dei based on Genesis 1:26 (we find only two direct quotations of this biblical verse in the whole Corpus Dionysiacum).

In the key question 93 of the Prima pars where Aquinas deals with the imago Dei he mentions Dionysius only briefly - generally only in matters related to comparison of men to angels and not when speaking about the image of God in man. Despite all of this, my aim in this paper will be to look at the notion of hierarchy in Dionysius and image in Aquinas in relation to man's way towards union with God and to explore whether there are some traces of Dionysius's teaching on hierarchies in the teaching of St Thomas related to the imago Dei in man.

1 According to Index Thomisticus in: Corpus Thomisticum: S. Thomae de Aquino Opera Omnia, ed. by E. Alarcón, Pamplona 2000 < http://www.corpusthomisticum.org/it/index. age $>$ [accessed 18 October 2019].

2 E. Reinhardt: Thomas Aquinas as Interpreter of Scripture in the light of his inauguration lectures. In: P. Roszak and J. Vijgen (eds.). Reading Sacred Scripture with Thomas Aquinas: Hermeneutical Tools, Theological Questions and New Perspectives, p. 78.

3 ST Ia, q. 108 and q. 112.

4 ST Ia, q. 1 a. 10 co. See also M. Mróz, Virtue Epistemology and Aquinas's Biblical Commentary to the Corpus Paulinum, in: Roszak, Reading Sacred Scripture with Thomas Aquinas, p. 205. 


\section{The role of hierarchy in Dionysius}

Let us now briefly consider the Dionysian hierarchy as described in his writings. The key passage in the third chapter of Celestial Hierarchy defines hier-

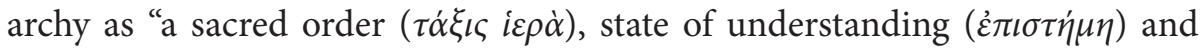

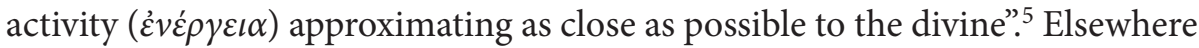
Dionysius describes the goal of all the hierarchy: "To enable beings to be as like as possible to God and to be at one with him." ${ }^{6}$ Here we may probably discern an echo of the $\delta \mu o i \omega \sigma \iota \varsigma$ from Gn 1:26, but it would seem that Dionysius sees the hierarchy at the same time as a possibility and as a process which enables man to imitate God - always in proportion to his abilities. "Hierarchy causes its members to be images of God", ${ }^{7}$ and once a person "has been lifted up into conformity with God through complete and perfecting divinization [...] he has become an image."

The important element in the hierarchy as a whole as well as in each of the particular hierarchies is not just the ordering but also the source of the hierarchy: God. Without God as the source and without his willing of this uplifting of the lower ranks towards the higher ones and finally towards the $\tilde{\varepsilon} v \omega \sigma \iota \varsigma$ would be impossible.

Let us now concentrate on the definition of a hierarchy - ordo, scientia and actio (to use the Latin terms as Aquinas renders them in the Summa theologiae) - by first looking at the actio. This activity consists itself of a triad of actions - purification, illumination, and perfection. All of these activities are primarily God's activities (or energies), even when they are performed by or upon the members of the hierarchy of various ranks -celestial or ecclesial. For example, as described in The Ecclesiastical Hierarchy, if a deacon is effecting purification on the catechumens during the rite of baptism, he is doing so in the name of the bishop - that is the hierarch who consecrated him, in the name of God, the source of every hierarchy. However, as Rorem points out in his com-

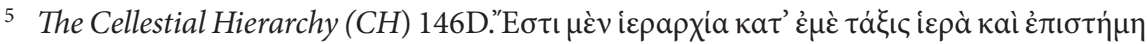

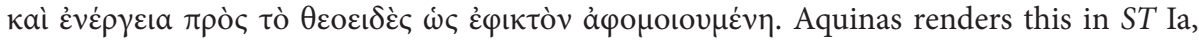
1. q. 108 , a. 2 , arg. 2 as hierarchia est ordo, scientia et actio.

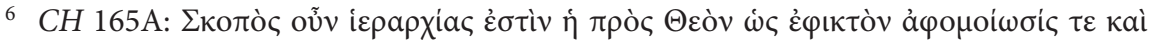

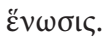

7 The Ecclesiastical Hierarchy (EH) 433C. If not stated otherwise, translations are taken from the Colm Luibheid translation in: Pseudo-Dionysius, The Complete Works. London 1987.

8 Ibid. 
mentary, unlike later usage of these three "ways", which includes moral and mystical implications, for Dionysius this three-fold action is all related to spiritual knowledge or understanding. ${ }^{9}$ In this sense it is possible to understand how Dionysius can speak of purification of the angels in the lower hierarchies of heaven - as diminishing their "non-knowledge" 10 by pouring divine illumination onto them by which they are led to more perfect and clearer knowledge and thus union with God. ${ }^{11}$

The second element in the Areopagite's definition of hierarchy is the scientia, $\dot{\varepsilon} \pi \iota \tau \eta \dot{\mu} \mu$. It is concerned with God's operations - although not with how he is in se, since, as Dionysius says, "that which is transcendent to being is also transcendent with regard to all knowledge" 12 and the creature might know God "by means of his participation alone." 13

The notion of knowledge itself has in Dionysius a hierarchical quality - the lower hierarchies receive their knowledge from their superiors; the higher hierarchies on the other hand are moved to share their knowledge with the lower ones - which reminds us of the first part of the "definition" - hierarchy as a sacred order that has both its source and its fulfilment in God himself.

The oft-repeated remark about the "passive" aspect of Dionysian can thus be understood in the sense that man cannot reach his goal - perfection, unification with God, $\varepsilon v \omega \sigma \iota \varsigma$ - by his own powers, but by the cessation of his natural activities (or in other words, by silence). Man has to "suffer God", who is ever more "active" in ourselves. ${ }^{14}$ This may be the way to understand Dionysius' use of the term $\varphi \iota \lambda \alpha v \theta \rho \omega \pi i \alpha$ - God condescends to us and "in the manner of a fire, likening the things united by the means of the union with himself, in accordance with their capacity for deification". ${ }^{15}$

From what has been said we can gain a clear impression that for Dionysius each rational being is - since it already has a certain degree of participation in the Creator - called to become the (full) likeness of the divine - based on the capacity which the Creator has given him and with the help of Grace. The "natural" divine similitude is not sufficient for reaching union with God alone. This is one of the reasons why the emphasis on the divine gifts and the soul's

9 P. Rorem, Pseudo-Dionysius, p. 59.

10 Aquinas translates it as nescientia, contrary to ignoranita.

11 EH 537 AB, see also R. Roques, Introduction, in Pseudo-Denys, La Hierarchie Celeste, p. lxxv.

12 The Divine Names (DN) I.4 593A.

13 DN II.7 645A, see also A. Golitzin, Et Introibo Ad Altare Dei, p. 107.

14 Ibid., p. 113.

15 Ibid., see also EH II.2.1 393A. 
dependence on God's gratuitous illumination is one of the major motifs in Dionysius' anthropology.

The fulfilment of man's goal - fullness of knowledge of God - happens in ekstasis, since it is beyond man's nature. This ekstasis is, however, also an ekstasis of God, since this "encounter" of Union happens "outside" of his essence - in his processions or energies. ${ }^{16}$

It is not possible to go through the whole of Dionysius' vocabulary here, but we will return to some of the key terms in further discussion.

\section{Dionysian influence on Aquinas}

Many studies have shown in both the more and less recent past that the influence of Dionysius on the Angelic doctor was not limited to the angelology or Divine naming mentioned earlier. ${ }^{17}$ Let us now examine Aquinas's teaching about the likeness of God in man. It would be overwhelming to trace the whole evolution of his thought on this topic, therefore, only the most mature teaching found in the Summa theologiae will be considered here.

As the previously mentioned Question 93 of Prima pars suggests St Thomas understood the image of God in man in a sense as a potential for knowledge of and love for God. ${ }^{18}$

Thomas distinguishes several degrees or levels in which the image of God can be found in man. The first level is the "natural" image - common to all mankind - which consists in the "natural capacity to understand and to love God [...] which resides in the very nature of the mind (consistit in ipsa natura mentis)". ${ }^{19}$ For Aquinas - similarly as for Dionysius - this "natural" similarity based on the reality of man's creation is insufficient for real union with God without the divine gift of assimilation. ${ }^{20}$ Dionysius considers the entire ascent

16 A. Golitzin, Et Introibo Ad Altare Dei, p. 115.

17 Among many see e. g.: F. O’Rourke, Pseudo-Dionysius and the Metaphysics of Aquinas. Leiden, Brill, 1992; A. Hofer, Dionysian elements in Thomas Aquinas's christology: A case of the authority and ambiguity of pseudo-Dionysius. The Thomist (2008) 72 (3):409442; A.P. Darley, The Epistemological Hope: Aquinas Versus other Receptions of PseudoDionysius on the Beatific Vision. Heythrop Journal (2018) 59 (4):663-688.

18 ST Ia, q. 93. For further reading on this topic see also R. Cessario, The Godly Image.

19 ST Ia, q. 93, a 4, resp.; English translation by A. J. Freddoso, Treatise on Human Nature, p. 265.

20 B. Blankenhorn, The Mystery of Union with God, p. 9. 
to God as beyond the capability of the soul itself - it is a gift of (hierarchicallymediated) divine light, in which Christ himself elevates the soul to the Father. ${ }^{21}$

Aquinas's view is somewhat more sophisticated. ${ }^{22}$ For him the next "level" in which man actually or habitually understands and loves God (cognoscit et amat) is connected with the "conformity of grace" (per conformitatem gratiae). ${ }^{23}$ The distinction between actual and habitual understanding and love is not mentioned in Question 93, but more can be found in the discussion about the division of grace. Aquinas distinguishes between gratia gratum faciens (usually translated as sanctifying grace), by which man is united to God and between gratia gratis data (translated as gratuitous grace) by which "one man cooperates with another in leading him to God" and "which is bestowed on a man beyond the capability of nature and beyond the merit of the person" - not, however, "to justify him, but rather that he may cooperate in the justification of another". 24

I would argue that this notion of conformity of grace, i.e., conformity with the things gratuitously given or worked by God, it may be possible to catch an echo of Dionysius. Indeed, the response regarding the division of grace starts with a quotation of the Areopagite: "The order of things consists in this, that things are led to God by other things, as Dionysius says. And hence since grace is ordained to lead men to God, it takes place in a certain order, so that some are led to God by others." 25 We see, therefore, in this order of grace not only a reference to the Dionysian hierarchical ordering but indeed we may notice that this unitive aspect grace is similar to the goal of the Dionysian hierarchy as a whole.

Another important question to consider is this: is the way to Union with God a purely divine activity or does man have to play a role as well? The Dionysian system is sometimes described in terms of "passive mysticism" - meaning the ascent towards Union is entirely God's work. It is in a certain sense true, but it cannot be fully true, because that would mean diminishing or negating human freedom. What Dionysius says is that although the "act" of union does come from God, there is - from the part of man - required some co-opera-

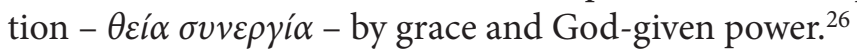

21 Ibid.

22 For contemporary discussion on Thomist philosophical anthropology see for example: D. DeHaan, The Interaction of Noetic and Psychosomatic Operations in a Thomist Hylomorphic Anthropology, Scientia et Fides 2(2018), 55-83.

23 ST Ia, q. 93, a. 4, resp.

24 ST Ia-IIae, q. 111, a. 1, resp.

25 Ibid.

$26 \mathrm{CH} 168 \mathrm{~A}$. 
Dionysius uses three terms to describe the condition of illumination or deification "as far as man is capable". He speaks of " $\dot{\alpha} \xi i \alpha$ " which is the merit of intelligence, necessary for divinisation. It does not exclude the divine gift, which is its pre-requisite, but it does include authentic activity of both the will and intelligence. He also speaks of $\sigma v \mu \mu \varepsilon \tau \rho i \alpha$ (commensurability) and $\alpha v \alpha \lambda o \gamma i \alpha$ (resemblance) that signify the relationship of man's reason (intelligence) to God. They both tell about the ideal (or maximal) measure in man for participation in the divine - which is ordained by God, has its source in God, and is directed towards God. In a certain sense the symmetry could be understood as the similarity, which is given to a created being, in the overflowing creative activity of God. The analogia seems to be a more complicated term - it has to do with both the "assigned place" in the hierarchy, the "given word" (logos), man's response to it and also with assimilation to this divine Logos. Again, it contains both the free initiative of God but also the free response of the rational creature. ${ }^{27}$ Already when reading The Divine Names we can perceive the nature of the process in which this "analogy" fulfils itself: Dionysius describes it in the manner of man's potential (faculty of intellection) which is filled with divine $\delta v v \alpha \dot{\alpha} \iota \varsigma$ in the act of $\tilde{\varepsilon} v \omega \sigma \iota \varsigma$ in which the mind transcends its nature and joins God. ${ }^{28}$ In his Commentary on the Divine Names, St Thomas explains the divine activity as unitionem ad res divinas per gratiam, which is effected per fidem aut quaqumque cognitionem. ${ }^{29}$ We see therefore that both divine and human initiatives - grace and faith - are indispensable for attaining perfection, which Dionysius describes as "perfect conformity to God".

Aquinas speaks of conformity to God in his commentary on the Divine Names where he sets a limit to the intellectual powers of our natural reason, which he considers "useless when our soul, having been conformed to God, throws itself into the divine things". ${ }^{31}$ This "throwing in" or grasping $(\dot{\varepsilon} \pi \iota \beta \alpha \lambda \varepsilon \nu v)$ divine things occurs by the movement of faith - coming from God and drawing man to God - by which the unknown and inaccessible divine light unites and communicates itself to man. ${ }^{32}$

27 R. Roques, L'Univers Dionysien, pp. 61ff. 


\section{Towards the union with God}

In Aquinas's works we observe a stronger emphasis on man's willpower compared to the Corpus Dionysiacum, where it might seem that the role of the will consists in agreeing with the divine action. For St Thomas, love - an act of will - is truly indispensable part of the ascent towards the union with God. When speaking about the image of the Trinity in man Aquinas explains that love goes hand in hand with understanding, which is an act of reason. Mirroring the life of the Trinity, understanding and love together bring about the realisation of the image of God but neither could do so alone. ${ }^{33}$

It should not be perceived that in Dionysius love for God plays no role in the way towards Union at all. In the Ecclesial Hierarchy he offers yet another "definition" of the hierarchy in which love and knowledge are intertwined:

The common goal of every hierarchy consists of the continuous love of God and of things divine, a love which is sacredly worked out in an inspired and unique way, and, before this, the complete and unswerving avoidance of everything contrary to it. It consists of a knowledge of beings as they really are [...] of both the seeing and the understanding of sacred truth, $[\ldots]$ of a feast upon that sacred vision which nourishes the intellect, and which divinizes everything rising up to it. ${ }^{34}$

As we can see, while knowledge remains the constitutive element of Union, without love it is impossible. ${ }^{35}$

In Aquinas's treatment of the image of God in man we find another element of love - the love of virtue - which might be traced to John of Damascus rather than Dionysius, but it may throw light on this topic ${ }^{36}$. As first among all the virtues St Thomas discusses the virtue of faith - a virtue of which the object as well as its source, as we read in the Summa, is God. ${ }^{37}$ And it is through an act of faith - which replaces the act of knowledge - that the soul "conformed to God" can move toward Him. ${ }^{38}$

The third and last "degree" in which the image of God can be found in man for St Thomas consists in perfect knowledge and love for God (secundum quod

\footnotetext{
33 ST Ia, q. 93, a. 5, see also B. Blankenhorn, The Mystery of Union with God, pp. 244ff.

34 EH 376A.

35 B. Blankenhorn, The Mystery of Union with God, p. 18.

36 ST Ia, q. 93, a. 9, resp.

37 ST IIa-IIae, q. 1, a. 1; q. 4, a. 2.

38 B. Blankenhorn, The Mystery of Union with God, p. 335.
} 
homo Deum actu cognoscit et amat perfecte) and Aquinas calls it a likeness of glory (similitudo gloriae). ${ }^{39}$ It is only found among the beatis in heaven, i.e., among those who are, so to speak, already out of this world, in an ekstasis.

In the Commentary on The Divine Names Aquinas speaks of our imitating the angelic union in holy silence, i.e., in repose of every intellectual activity, and in praising God through negation or rather remotion of all beings. ${ }^{40}$ In such way these deiform minds, whom St Thomas identifies with souls that have received the gift of sanctifying grace, are illumined by the union with the Light. ${ }^{41}$

\section{Conclusions}

From all that has been said we can gather that for both Dionysius as well as Aquinas God is the source as well as the final end of man. At the beginning of this paper I mentioned that Dionysius only once directly speaks of the "image and likeness" from Gn 1:26. That particular place in the Divine Names reminds us of the exitus - reditus pattern that we also encounter in St Thomas: "[God] bestows a similarity to himself on all those who are returning to him in imitation as far as possible, of what is beyond all definition and understanding. It is the power of the divine similarity which returns all created things toward their cause, and their image and likeness." 42

The locus of this "way of return" par excellence is for Dionysius the hierarchy, especially the way of the sacraments of the Church. It should be noted that every time Dionysius directly describes what might be called a mystical union in his writings, it is always closely connected to the celebration of the synaxis, that is, the Eucharist, ${ }^{43}$ which forges divine unity, brings about perfection and is the fulfilment of hierarchy. ${ }^{44}$ It would seem, however, that this "liturgical setting" of Dionysian union is not noticed by Aquinas, nor is he aware of allusions to the liturgical symbols often referenced as starting points on the way towards the union by Dionysius ${ }^{45}$ - which is something that might have been lost in translation.

39 ST Ia, q. 93, a. 4, resp.

40 DN 593C, see also DDN, ch. 1, lect. 3, no. 83. English translation from B. Blankenhorn, The Mystery of Union with God, pp. 336f.

41 DN 593C, see also Y. Andia, Henosis, pp. $237 f$.

42 DN 913C.

43 B. Blankenhorn, The Mystery of Union with God, p. 17.

44 EH 424C.

45 B. Blankenhorn, The Mystery of Union with God, p. 334. 
We have seen that the teaching of Pseudo-Dionysius about hierarchies has influenced the teaching of the Angelic Doctor in many areas, and even though in his thinking about the way towards the union with God or beatitude this influence is perhaps less obvious there are still traces to be found, both in the teaching about the image of God in man as well as in what is related to the presence of this imago in man - the life and acts of faith. Although in general man's role in the ascent or return to God is presented as less passive in St Thomas than in Dionysius, still, as Aquinas himself says, "man is made a member of Christ through grace alone". ${ }^{46}$ Even for him the way to God is paved "both by the merit that derives from the actions of man's own graced free will and by the unmerited gifts of conversion and perseverance - brought about by prevenient grace of God" ${ }^{47}$

\section{References}

Andia, Y., Henosis: L’union a Dieu Chez Denys Laréopagite. Leiden 1996.

Aquinas Thomas, Summa Theologiae. Lander, WY 2012.

Aquinas, T., Freddoso, A. J.(transl.), Treatise on Human Nature: The Complete Text (summa Theologiae I, Questions 75-102). South Bend 2010.

Aquinas, T., In Librum Beati Dionysii De Divinis Nominibus Expositio. Marietti ed., Turin - Rome 1950.

Blankenhorn, B., The Mystery of Union with God: Dionysian Mysticism in Albert the Great and Thomas Aquinas. Washington, D.C. 2015.

Cessario, R., The Godly Image: Christ and Salvation in Catholic Thought From St. Anselm to Aquinas. Petersham, 1990.

Golitzin, A., Et Introibo Ad Altare Dei: The Mystagogy of Dionysius Areopagita, with Special Reference to Its Predecessors in the Eastern Christian Tradition. Thessaloniki 1994.

Pseudo-Denys, La Hierarchie Celeste. SC 58, Paris 1958.

Pseudo-Dionysius, Luibheid, C. (transl.), The Complete Works. London 1987.

Roques, R., L'Univers Dionysien: Structure Hiérarch. Du Monde Selon Le Pseudo-Denys. Latour-Maubourg 1983.

Rorem, P., Pseudo-Dionysius: A Commentary on the Texts and an Introduction to Their Influence. New York 1993.

Roszak, P., Vijgen, J. (eds.), Reading Sacred Scripture with Thomas Aquinas: Hermeneutical Tools, Theological Questions and New Perspectives. Brepols, Turnhout 2015.

Spezzano, D., The Glory of God's Grace: Deification According to St. Thomas Aquinas. Ave Maria, FL, 2015.

46 ST III, q. 62, a. 1.

47 D. Spezzano, The Glory of God's Grace, note 94. 